\title{
TOWARDS A NEW EU: WHY POPULISM CAN SAVE THE EUROPEAN UNION
}

\author{
Alessandro Giuseppe Drago \\ McGill University
}

\begin{abstract}
Europe has seen an alarming increase of populist parties throughout the last two decades. The European debt crisis has only added to their strength and support, and Eurosceptic attitudes have only increased, as exemplified by the recent Brexit vote. However, this exploratory paper will argue that the crisis to which populism has given rise allows the EU to critically reflect on itself and fix many of the fatal flaws that the increase in populist support has pointed out. It will be argued that the EU needs to create a strong civic society to help mend its democratic deficit. Finally, it will be argued that by incorporating particular elements of populist thought and critique (i.e., democratization and fairer economic policies), that is, implanting an "alter-europeanization," that the ugly side of populism (its xenophobia and racism) will begin to lose support within European countries.
\end{abstract}




\section{Introduction}

For the last twenty years, support for populist parties has dramatically increased throughout Europe and has posed challenges for the consolidation of the European Union (EU). Many of these populist parties are right-wing and express xenophobic attitudes and beliefs. Some of these populist parties also seem to hold liberal democracy in disregard, such as Hungary's Fidesz, or Poland's Law and Justice (PiS) party. Populist support in Europe ranges from very low in Croatia and Portugal to very high in Italy (over 50\% of Italians voted for a populist party in 2013) (McDonnell and Bobba $2015,163)$. The rise of populist support has created veritable crises for the EU and its member countries, most recently with the 2016 Brexit referendum. The development of populism in Europe is tied to the specific national/political circumstances and structural conditions in each country, which is why populism has not appeared at similar times and with similar intensity in every European country (Kriesi 2016).

Though the rise of populism has alarmed politicians and academics alike, its surge gives us the ability to diagnose the very real problems plaguing the EU. The rise of populism (in particular, the very dangerous right-wing populist xenophobia) allows the European Union the chance to critically reflect on itself in order to "fix" its various issues. Populist strength and support - from either end of the political spectrum - needs to be viewed as a form of referendum on the EU's performance. I argue that, in order to stem the tide and the recent successes of extreme populism, the EU needs to create a viable and thriving public sphere. This public sphere would help create and foster a European identity and the values that Europe avows such as democracy, diversity, and tolerance - values that are being challenged by some of the current populist parties in European countries.

This paper will first discuss the effect that the intertwined though distinct processes of globalization (in its economic, political, and cultural senses) and economic modernization have had on Europe, and how this influences populist support. Overall, this argument will draw heavily from the "globalization's losers" thesis (Kriesi et al. 2008), while also emphasising how the negative effects of economic modernization (which is an internal change to a country's mode of production) help shed some valuable light on the rise of populism today. The following section discusses the idea of a democratic deficit at both the supranational (in the EU) and national levels. This paper argues that the "depoliticization" of political parties, as well as the perception that mainstream political parties in Europe are mostly indistinguishable from one another, increases populist support. The final section uses three cases of left-wing populist victories in Southern Europe to suggest that political parties in Europe need to return to organizing strategies that mobilize the masses. Furthermore, the European Union itself would benefit from creating a viable public sphere to facilitate debate and incorporate challenges, as well as to create a civic conception of European identity, something that is distinguished from the dangerous nativism of populist parties that tie nationalism to ethnicity. This all entails a strategy of alter-Europeanization, whereby the EU should attempt to change the course of its European project to better reflect and incorporate the reality on the ground. This alter-Europeanization is being put forward by recent social movements and by populist left parties in Southern Europe today.

This essay will also discuss another aspect of the EU's complicated relationship with the democratic norms usually associated with a state. The unprecedented and unfamiliar character of supranational governance has not mobilized a corresponding form of supranational social 
movements, that is, issue movements that are genuinely transnational in organization and in character. This lack of grassroots political mobilization should be seen as a failure of the European Union to create a well-established/integrated public/civil sphere for Europeans to voice their displeasure. Because social movements focus primarily on national governments, those governments are more likely to create Eurosceptic policies, and, in the process, states with large social movements are more likely to have Eurosceptic parties arise. This idea builds on Habermas's (2016) belief that the creation of an economic union cannot supersede and should never precede the establishment of a civil society. It is important to preface the following discussion with some statistics from the Eurobarometer survey, which found that only $40 \%$ of Europeans trust the European Union, while only $41 \%$ of Europeans hold a positive view of the EU (Eurobarometer 2015). These results indicate that the EU is widely unpopular (note that the rest of respondents either viewed the EU as "negative" or as "neutral").

\section{Definition of Populism}

Laclau $(2005 ; 2006)$ created one of the more fruitful definitions of populism to date, despite its various criticisms (Zizek 2006a; Zizek 2006b, 197; Moffitt 2015, 191). For Laclau, all politics involves the discursive construction and articulation of the 'people,' and therefore, all politics is necessarily populist. Ideologies as diverse as fascism, socialism, and communism can all be considered populist, since they all involve the articulation of a common social/political actor that is necessarily differentiated from some other. Importantly, populism isn't only about discourses of difference, since populist discourse is inherently antagonistic (Laclau 1977, 174). Not only are the 'people' different from the 'others' (usually those of a different class, social status, or ethnicity), but they are also in a battle to reclaim their democracy and their country from these antagonistic forces. The problem with populism, according to Laclau, is that the "will of the people" is so heterogeneous that populism, which purports to represent the people, may not be the right ideological fit for all citizens (Laclau 2005).

Other scholars state that populism should be considered as a "thin" ideology because of its ability to be used by fully-developed and already-established political principles (either right or left ideologies) (Stanley 2008, 95). In other words, populism merges with a more "comprehensive" or "programmatic" ideological base (ibid., 99-100), and it should be considered as a "partner" that attaches itself to the traditional political ideologies of today (ibid., 107). This explains the wide diversity of policies, ideologies, and actions represented by populist parties throughout the world and why populism can be used in conjunction with both left and right-wing ideologies (Albertazzi and McDonnell 2008, 3).

Very generally, populists see themselves as the "true democrats," who must rescue democracy from its abuse by corrupt politicians (Albertazzi and McDonnell 2008, 4). Populists tend to claim that they cannot be placed on the ideological/political spectrum. The common denominator of populist parties is the articulation of the 'people' as a homogenous mass who are differentiated and confronted by some 'other(s).' Populism puts the 'people' at the forefront of politics and wishes to bring democracy back into the hands of the 'people' and out of the hands of the corrupt elite (Stanley 2008, 107). The specific characteristics of the 'people' referred to by populists depend on the economic, cultural, and political characteristics of the state in which they find themselves (Pappas and Kriesi 2015, 4). These 'others' can be politicians, corporations, and more 
recently, immigrants. Importantly, because populism is a 'thin' ideology, the specific 'others' in populists' discourse will depend on where they draw their 'thick' content from, i.e., if they draw from right-wing ideology, they are more likely to have an "ethnic view of the "people" (Pappas and Kriesi 2015, 5).

Populists also tend to appeal to the so-called 'silent majority,' who are taken for granted and fed up by their treatment by mainstream politicians. They believe that the democratic process is being hijacked by others who don't have the interests of the population at large in mind. Populists tend to reject representative democracy, claiming that it is corrupt, and instead are willing to experiment with direct democratic initiatives such as referendums or "citizen hearings" (von Beyne 2011; Biorcio 2014; Hartleb 2015, 48).

Because of this conception of democracy, many scholars consider populists to be illiberal (Pappas and Kriesi 2015, 5; McDonnell and Bobba 2015, 165; Pasquino 2008). Liberal democracy ensures that there are checks and balances to guarantee that power is not monopolized by one single entity (such as the judiciary or the president) or by the people (Montesquieu 1949). Populists typically reject constitutional constraints and the power of unelected judges (Zaslove 2008, 321). Constitutional democracy prevents the tyranny of the majority from taking rights away from minority population (Tocqueville 2000). However, populists in Europe and the United States are often at odds with minority rights. Therefore, populism rejects democracy with constraints (constitutional restraints, for example) (Canovan 1999, 10). This presents a paradox of populist parties advocating for democracy while also implementing policies that will limit democratic freedoms for others (Fryklund 2013, 268).

\section{Two Major Theses}

This section discusses two primary theses that attempt to explain why populism has arisen in Europe. First is the claim that, due to economic liberalization, citizens in European countries are now divided between those who benefit from globalization and those who do not. Second is the idea that the perceived democratic deficit at both the EU and national levels has contributed to a rise in populist sentiment. These two contributing factors to populist support outline the problems inherent in the European Union. Populist parties are well-positioned to articulate these problems into political platforms, and are thus supported by individuals who are disgruntled by the EU.

\section{Globalization's 'losers'}

The first thesis deals with the processes associated with economic globalization, whereby national economies became gradually integrated with the rest of the world and economic competition for global market share increased. Globalization is generally taken as one of the major causes of welfare/pension reform and cuts within countries (Mouffe 2016). Economic modernization, whereby the economy is continuously in a process of losing manual/industrial labour and placing more emphasis on non-manual labour, tends to occur at the expense of working class/blue-collar workers. In one of the most recent Eurobarometer surveys, 42\% of Europeans believe that unemployment is the biggest issue facing their respective countries (Eurobarometer 2015). 59\% of Europeans see the economy in their respective economies as being "totally bad," which indeed reveals the dire economic situation Europeans believe they are facing (ibid.). 
A growing body of research finds that supporters of populism are the so-called 'losers' of globalization. With the disruption of national economic boundaries, the nation-state is less able to guarantee a given level of job security and/or welfare state provision than it was in the immediate post-war economic period of growth (Kriesi et al. 2006; 2008; 2012). Furthermore, because of the slow erosion of economic sovereignty, national politicians and advisors are unable to problemsolve as efficiently as before the period of globalization, since the economy has become more intertwined with global economic forces. Thus, those most affected by the ills of globalization will hold negative views of their politicians, since they seem powerless to change the status quo (Kriesi et al. 2008).

The integration of European states into an economic union, where "competitiveness" is one of the major guiding principles, poses problems for the consolidation of a state's social programs (Fontaine 2014). Since the late 1970s, Western European countries have increasingly experienced welfare retrenchment in the form of cuts to social services such as education and pensions. With these cuts to fundamental social programs, many individuals now find themselves without the proper support structures to allow them to cope with hardening economic times.

The "globalization's losers" thesis can be supplemented with the work of Betz (1994), who has argued that the modernization of the economy has created a division within the working class. For Betz, populism in Europe emerged because of the effects on society of the shift from an industrial to a post-industrial economy. This shift created an economic underclass of individuals who felt that they were left behind by the economy (ibid., 33). This new post-Fordist economy (Virno 2004) increased the amount of non-manual labourers and the importance of the professional classes, at the expense of the traditional industrial worker. These processes have also led to an increase in the level of precariousness faced by traditional labourers, since their jobs are at the mercy of global economic forces.

What Betz's (1994) thesis allows us to understand is that the lifestyles and opportunities of a worker in a Fordist economy versus a post-Fordist economy are radically different. Consequently, the interests and concerns of workers formerly engaged with the manufacturing sectors will change, which is very likely to inform their voting habits. Although Kriesi et al. (2008) focus more on the integration (economic and cultural) of nation-states into the global sphere, while Betz (1994) discusses the quantitative and qualitative shift in the composition of the labouring class in Europe, these processes are overlapping, and can each be understood to have created large amounts of individuals with legitimate economic grievances.

Both theses find broad empirical support in the literature. France's Front National party attracts many voters exploited by globalization (Wacquant and Halimi 2002). They are able to attract them because the left has abandoned this segment of the population in favour of neoliberalism (ibid.). Marine Le Pen has really positioned herself against globalization, neoliberalism, and adherence to the free market (Betz 2015, 82). Generally, right-wing populist parties have found a way to allow those who have suffered from globalization to "articulate their anger" better than left-leaning parties (Pelinka 2013, 11). In the UK, those who felt "left behind" were more likely to vote for the Independence Party (UKIP) (Goodwin 2015, 284). The "globalization's losers" thesis is also applicable in Switzerland, since its economy has faltered, and neoliberal economic policies have reduced benefits and job security (Albertazzi 2008, 115). Populism only emerged once the Swiss felt the pressures of globalization and felt threatened by it (Albertazzi 2008, 115). 
Furthermore, the main supporters of right-wing populists are workers who have suffered the most from globalization and from pension cuts (Pelinka 2013, 11). In one study, production workers (factory workers, mechanics, etc.) were the most supportive of right-wing populist parties in their respective countries. Service workers had the highest support for the Front National in France, and small business owners were also more likely to support right-wing populist parties in all countries sampled. The populations that did not support these parties were the self-employed and the professional class (Oesch 2008, 357).

The economic foundation of the ethno-nationalist ideology that many European populist parties espouse may lie in the perceived link between rising unemployment and rising immigration. Studies show that voters for right-wing parties were more concerned with cultural issues than economic ones. Therefore, it appears as though the motivation to vote for a right-wing populist party stems more from cultural/moral issues. This is well evidenced by the fact that the two categories of people in the weakest and most perilous position in relation to globalization, production and service workers, are more likely to emphasize "cultural grievances over immigration" as the main factor dictating their voting choice, rather than economic ones (Oesch 2008, 370).

Another study found that all right-wing populist parties mobilized anti-immigrant rhetoric during the elections of 2002-2003. This grievance was invoked more than others such as economic grievances by populist right parties (Ivarsflaten 2008, 17). The one common denominator shared by all populist-right parties is their mobilization of anti-immigration rhetoric as their main grievance during elections (ibid., 18). This falls in line with much research done on specific populist parties, where cultural issues were more likely to be mobilized by the parties (Bernhard et al. 2015, 133; Yla-Anttila and Yla-Anttila 2015, 68; McDonnell and Bobba 2015, 165).

Why are cultural issues such as immigration and Islam dividing working class voters in Europe? One answer seems to be that, on economic issues, the left can no longer distinguish itself from the right, and therefore, the real demarcation line between political parties is not on the economy, but on cultural values (Maradal 2013, 51). This strategy was used by Republicans in the United States during the "culture wars" of the late 1980s and 1990s in order to differentiate themselves from the Democrats, since the two parties are virtually indistinguishable from each other on economic issues (ibid., 52). The economy and issues surrounding the economy become depoliticized while issues of immigration are prominently politicized (ibid., 53). As a strategy, Maradal argues that the left should return to more welfare-based, democratic, and egalitarian politics to attract those who have stopped voting for them (ibid.).

In conclusion, it appears that one of the reasons working class individuals will vote for right-wing populist parties is that the traditionally left-wing political parties have become - in the perception of some voters - neoliberals. Because these parties have abandoned their traditional economic policies, in worsening economic conditions, the working class has become attracted to populist rhetoric and some of its xenophobic sentiments. Finally, it is important to remember that populist right parties are likely to "reframe economic conflicts in cultural terms" (Pappas and Kriesi 2015, 8). The fear of immigrants stems not only from right wing populists' fear of ethnic heterogeneity, but also from fears that immigrants are harming the economy by taking away jobs, for example, or being welfare-dependent. 


\section{Perceptions of Democratic Deficit}

Populism is a reaction fueled by the belief that the democratic system has not responded to the needs and desires of its citizens. People who do not feel represented by the institutions that are in place are more likely to be attracted by populism (Pelinka 2013,4). This section of the paper will discuss the perceived democratic deficit found not only in the EU, but also within European national governments, and it will be argued that one of the main drivers of support for populism is the perceived democratic deficit in most political institutions today.

This perceived democratic deficit in Europe was partially created by the reduction of domestic power over economic issues. Citizens have lower levels of trust that their governments have the capacity to make substantive decisions or the ability to fix problems as expediently as before (Eurobarometer 2015). As we saw above, economic concerns are some of the biggest reasons why individuals vote for populist parties. The belief that economic issues are decided somewhat autonomously from national institutions tends to delegitimize ruling parties and creates the belief that these parties are powerless in the face of the EU.

However, besides the issues raised above, there are two major factors that contribute to the perception of a democratic deficit in EU member states. The first deals with the end of mass-based organizational strategies in political parties today (Zaslove 2008, 325), which tend to be highly bureaucratized, hierarchical, and run by a sophisticated team of "experts" with less input from citizens or supporters of the party (Mastropaolo 2008, 46). A substantive change has slowly occurred in the organization of political parties, where they went from being open and highly participatory organizations to tightly controlled organizations with power increasingly vested in the hands of bureaucrats. The high levels of donations given by corporations and private donors further delegitimize political parties in the eyes of voters (ibid.). This represents a real failure on the part of representative democracy (which populist parties such as UKIP criticize), in the way that politicians have been unable to respond to their constituents' demands and seem to be favouring large corporations or special interest groups (Pappas and Kriesi 2015, 2; Seymour 2015, 40).

The second issue is that the perceived indistinguishability of the major parties on economic issues has led to electoral volatility and low voter turnout. This, in turn, has helped create the "space" for populists to exploit (Zaslove 2008, 325). In other words, one of the main contributors to the perceived democratic deficit is the movement of the mainstream political left and right to the centre, making their economic policies relatively indistinguishable from one another. The impact of this movement is that the status quo is supported by all mainstream parties, with no real alternative viewpoints. For example, in response to the economic crisis, most mainstream parties implemented austerity measures regardless of where they fell on the political spectrum. Voters who opposed austerity were stuck with limited options in terms of voting choice (Löwry and Sitel 2015, 59). Having a conflation of indistinguishable parties makes it easy for populists to lump all politicians into one corrupt political class (ibid.). Furthermore, when the response to the crisis of capitalism by most mainstream parties has been more neoliberalism, voter frustration is understandable (ibid.). A viable alternative party is unlikely to appear at the centre, since this political space is most often occupied by mainstream parties. In such political climates, extreme parties are more likely to gain political victories. 
Laclau states that, because social democratic parties in Europe accept the status quo and the implementation of austerity measures, and because there seems to be no alternative, voters increasingly support right-wing populist parties $(2011,2)$. The crisis of populism is therefore the indistinguishability of the centre-right and centre-left, since alternative debate is not presented and neoliberal globalization seems like the only option (Mouffe 2016). All of the above contributes to a feeling of disenchantment with politics and causes withdrawal and disengagement from the political process, which might explain the reasons for the low voter turnout rates in elections in Europe and North America. This might be why populist parties tend to be led by charismatic leaders who present themselves as outsiders from the political establishment and as members of the common people (Albertazzi and McDonnell 2008, 4). Populists may be rejecting the depersonalized face of modern political parties and bureaucracies (Weber 1978).

\section{Democratic Deficit in the European Union}

Mair argues that the absence of any "real" opposition in Europe (since most mainstream parties accept European integration) has allowed more radical opposition to emerge $(2007,6)$. Because of the status-quo belief that European integration was important and needed no debate, classical opposition gave way to anti-systemic opposition. Therefore, instead of opposing the manner in which European integration was occurring, some political parties chose to oppose Europe altogether (ibid., 7).

This is caused by the fact that the EU is a depoliticized entity (Mair 2007, 7). The potential political channels used to criticize or help reform the EU (the European Parliament is one) are incapable of enabling citizens to hold the EU accountable for its actions (ibid., 12). Opposition to the EU is also stunted by the fact that national governments have lost some of their capacity to make decisions in their countries since power is delegated to unelected "experts" - at the European Commission, or at the European Central Bank, for example. Furthermore, the policy options of national governments are also restricted, since the EU rejects policies that "interfere with the free market" (ibid., 13-14).

For example, there was little internal debate over the EU accession membership referendum in 2004, and most of these referendums received record low turnouts for their respective countries, ranging from $45.62 \%$ to $64.04 \%$ (Szczerbiak and Taggart 2004, 559). The lack of debate indicates that, with the issues raised above, debate amongst mainstream political parties is limited. Turnout at European elections is also very low, and only $42 \%$ of Europeans believe that their voice counts in European elections (Eurobarometer 2015).

The installation of Mario Monti's unelected technocratic government, which was supported by the EU, imposed widely unpopular austerity measures on the Italian population (McDonnell and Bobba 2015, 170). The unelected institutions of the EU also dictate to national parties how they should behave and which policies they should implement. Both PASOK and New Democracy (the two major Greek parties at the time) were told by international and European creditors to end their populist rhetoric and become more liberal (Pappas and Aslanidis 2015, 188). Furthermore, the Lisbon Treaty's proceedings were "blatantly elitist," given that Ireland (after failing in a referendum to ratify the treaty) was asked to hold a second referendum in order to make the "right" choice (Habermas 2009, 81). 
The clearest examples of how the European Union is a depoliticized entity can be found in the study of social movements. The social movement literature finds that national governments are still the primary targets of protests rather than transnational entities such as the EU (Imig and Tarrow 2001, 34; Bush and Sini 2001, 102; Ortiz et al. 2013, 34). Like political parties, civil society organizations (social movements) can be placed on the hard/soft Eurosceptic dimension. One author found that there are indeed plenty of Eurosceptic civil society organizations in Europe (Fitzgibbon 2013, 118). However, a transnational social movement to protest the EU has not emerged, with many social movements lacking any kind of pan-European identity (Klandermans et al. 2001, 94). One study found that the visibility of the EU and issues revolving around it in the public sphere in nine sampled European countries was low. Newspaper coverage was predominantly focused on national issues, and even in countries deeply affected by austerity measures (such as Greece), the visibility of the EU in public debates and in general media coverage was very low (Monza and Anduiza 2016, 518).

This relative lack of dissent leveled directly towards the European Union by social movements should not be celebrated as the public acceptance of integration, but rather as an indication that the EU has failed to implement and carry out its goal of creating a European public sphere. One of the reasons Euroscepticism is so high and social actors petition their national governments for change is that they lack an adequate channel to challenge the EU and its policies. This has the unfortunate effect of causing national governments and political parties to take anti-EU stances because of the strong pressures they feel from their constituents. Rather than the EU being able to listen to and implement some of the critiques articulated by these social movements, it is sheltered from them, leaving national governments to face the brunt of the critiques. Because of this, national governments may try to deflect blame towards the EU, thus further undermining its legitimacy in the eyes of the European public.

\section{Social Movements, the Public Sphere, and Saving the EU}

The anti-austerity protests which swept across Europe from 2011 onwards were an indication that many Europeans were disgruntled by their political and economic situations (della Porta 2015). Greece's SYRIZA, Spain's Podemos, and Italy's Five Star Movement emerged from these social/political protests against austerity. Podemos's rise is intimately tied with the 2011 Indignados social movement in Spain, which advocated more citizen control and more direct democratic initiatives (Kioupkiolis 2016, 101). SYRIZA and the Five Star Movement also emerged and gained support through the massive mobilizations against the austerity measures of their respective governments (Biorcio 2014, Kartizis 2015, Vampa 2015).

One of the arguments being made in this essay is that, in order to combat the rise of right-wing populism and its corresponding xenophobia, political parties need to turn back towards civil society and the most marginalized. The radical left's heavy ties with civil society (primarily with unions and social movements) in Greece, as well as in Spain and Italy, have allowed them to consolidate and stay connected with their base. Furthermore, because they refused to accept austerity and other government policies (though SYRIZA did eventually accept these policies, which upset their supporters, of whom $80 \%$ of those in lower economic positions voted against the austerity measures) (Ioakimoglou 2016), and actively supported the political/social mobilizations against these policies, they were spared the legitimacy crisis that Greek/Italian/Spanish 
mainstream political parties suffered during the Euro area crisis (Tsakatika and Eleftheriou 2013, 14). Parties such as SYRIZA were on the streets with the protestors and activists and were thus better able to gain visibility (Stavrakakis and Katsambekis 2014, 126). Finally, and most importantly, SYRIZA (as a left-wing populist party) acts as a check to the rise of Golden Dawn (a right-wing fascist/populist party), since without SYRIZA, Golden Dawn support would have become much stronger (Kartizis 2015, 379).

Ties to civil society and grassroots political activism are needed in order to attract people to conventional mainstream political parties. By reconnecting with the popular base, conventional political parties can channel some of the energy and critiques into their own political base rather than allowing them to go to right-wing populists. In Spain, Italy, and Greece, three major left-wing populist parties created broad popular movements and held large rallies to energize voters.

Prominent European intellectuals have also weighed in on the recent populist phenomenon in Europe. Habermas and Derrida, like Negri (2009), view Europe as a counterweight to American imperialism and unilateralism (Habermas and Derrida 2003, 293; Habermas 2009, 89). For them, Europeans have an affinity for justice and equality; they generally prefer and support welfare-state policies, and are suspicious of the market. These authors argue that the values Europeans cherish, such as separation of church and state, liberalism, and equality, should instead form the basis of a common identity (Habermas and Derrida 2003, 295). Europe needs to build a public/civic sphere similar to the one that nations inherently have within their own borders (ibid.).

For Habermas, the European Union's problems stem from its preference for creating an economic union before and over a European public sphere (Habermas 2009). Without creating a common public sphere for Europeans, and by imposing unpopular economic policies, the EU lacks legitimacy in the eyes of Europeans (ibid.). Furthermore, Habermas argues that nationalism and right-wing populism, as well as a general sense of resentment, which is increasing in Europe, are all due to the failure of trickle-down economics to fulfill its promises (Habermas 2016). This resentment is being channeled most by the populist right, which is thereby gaining votes from the most disenfranchised and marginalized (ibid.). As a result, the mainstream left finds itself in a dilemma that it needs to address.

This paper raises two important points made by scholars analyzing the rise of right-wing populist sentiment in Europe. First, on the supranational level, the EU needs to attend to the public perception of democratic deficit by implementing more open channels for debate and dissent (Mouffe 2016) and ending unpopular economic/political actions when possible. This can be done by returning to the member states some of the control they once had over economic issues, and by giving national parliaments more control over the decisions and constitution of the European Union (Habermas 2016). Second, on the national level, an alternative economic program must develop in order to sway the voters who are most disaffected by neoliberalism, precarious labour conditions, and welfare retrenchment; these economic programs have already been articulated by parties like Podemos and SYRIZA (Laclau 2011, 3; Habermas 2016). Furthermore, left-wing parties should follow the example of Southern European parties and attempt to reconnect with the popular base. This can be done through outreach initiatives, by establishing strong links with unions, grassroots organizations, and other elements of civil society. In addition, political parties can experiment with social media, explore online forms of democracy (as the Italian Five Star Movement has done), and re-energize their youth wings. This will cut the support of right-wing 
populists and leave them only with their xenophobic and anti-immigrant rhetoric to distinguish them from the left.

Finally, surveys of Europeans found that $50 \%$ of them have some civic conception of a common European identity. This is more likely amongst people who speak more than one language, travel to other EU countries, or belong to pan-European organizations, as well as those with higher incomes (Fligstein et al. 2012, 117). Importantly, it is the "winners" of EU economic integration who have the highest levels of support for a collective European identity (ibid., 118). Traditional (industrial) workers tend to hold negative views of the EU and demand that their national governments protect them from EU market forces; they are thus unlikely to support or to end up cultivating a collective European identity (ibid.).

In conclusion, it is important to remember that these three examples of far-left populist parties are not against European integration as a whole. Rather, they wish to establish a new "social Europe" that accounts for the interests of those most marginalized (Kriesi 2016, 43). These left parties wish to implement a "European-wide solidarity" (ibid., 45). For them, the European project seems most at risk from forces on the right, who typically reject both cultural integration and the economic integration of the European Union. The Habermasian project of creating an inclusive and democratic Europe would seem to have its greatest potential in the form of left-wing populist parties. These may point the way to an alter-Europeanization that would help the European Union remain together and prosper.

\section{Conclusion}

Why can populism save the EU? Because it allows the EU to reflect critically on itself and discover which elements need to be reformed. Without any challenge, it would continue towards a path of economic liberalization without the corresponding social, political, and civic spheres required to create a common European identity. Populism allows the EU to realize that it has failed to cultivate a European identity and to curb a dangerous form of nationalism that has increasingly been emerging. Embarking on a process of alter-Europeanization, one that left-wing populist parties are attempting to articulate today, might be a fruitful way for the EU to curtail the rise of right-wing nationalist populist parties, stem the tide of xenophobia, and ultimately eradicate the Eurosceptic attitudes gaining prominence amongst Europeans today. 


\section{REFERENCES}

Albertazzi, Daniele. 2008. "Switzerland: Yet Another Populist Paradise." In Twenty-First Century Populism: The Spectre of Western European Democracy, edited by Daniele Albertazzi and Duncan McDonnell, 100-118. New York: Palgrave Macmillan.

Albertazzi, Daniele and Duncan McDonnell. 2008. "Introduction: The Sceptre and the Spectre." In Twenty-First Century Populism: The Spectre of Western European Democracy, edited by Daniele Albertazzi and Duncan McDonnell, 1-14. New York: Palgrave Macmillan.

Bernhard, Laurent, Hanspeter Kriesi, and Edward Weber. 2015. "The populist discourse of the Swiss People's Party." In European Populism in the Shadow of the Great Recession, edited by Hanspeter Kriesi and Takis Spyros Pappas. Colchester, U.K: ECPR Press.

Betz, Hans-Georg. 1994. Radical Right-Wing Populism in Western Europe. New York: St. Martin's Press.

von Beyne, Klaus. 2011. "Representative Democracy and the Populist Temptation.” In The Future of Representative Democracy, edited by Sonia Alonso, John Keane, Wolfgang Merkel and Maria Fotou. Cambridge; New York: Cambridge University Press.

Biorcio, Roberto. 2014. "The Reasons for the Success and Transformations of the 5 Star Movement." Contemporary Italian Politics 6 (1): 37-53. doi: 10.1080/ 23248823.2014.884376

Bush, Evelyn and Pete Sini. 2001. "European farmers and their protests." In Contentious Europeans: Protest and Politics in an Emerging Polity, edited by Douglas R. Imig and Sidney G. Tarrow, 97-124. Lanham, Md.: Rowman and Littlefield.

Canovan, Margaret. 1999. "Trust the People! Populism and the Two Faces of Democracy." Political Studies 47 (1): 2-16. doi: 10.1111/1467-9248.00184

della Porta, Donatella. 2015. Social Movements in Times of Austerity: Bringing Capitalism Back into Protest Analysis. Cambridge: Polity Press.

Eurobarometer. 2015. "Public Opinion in the European Union." European Commission. URL: http://ec.europa.eu/public_opinion/archives/eb/eb83/eb83 first_en.pdf

Fitzgibbon, John. 2013. "Citizens Against Europe? Civil Society and Eurosceptic Protest in Ireland, the United Kingdom and Denmark.” JCMS: Journal of Common Market Studies 51 (1): 105121. doi: 10.1111/j.1468-5965.2012.02302.x

Fligstein, Neil, Alina Polyakova, and Wayne Sandholtz. 2012. "European Integration, Nationalism and European Identity.” JCMS: Journal of Common Market Studies 50 (s1): 106-122. doi: 10.1111/j.1468-5965.2011.02230.x

Fontaine, Pascal. 2014. "How the European Union works.” European Commission. Luxembourg: Publications Office of the European Union. URL: http://europa.rs/images/publikacije/ HTEUW How the EU Works.pdf 
Fryklund, Björn. 2013. "Populism: changes over time and space: a comparative and retrospective analysis of populist parties in the Nordic countries from 1965 to 2012." In Right-Wing Populism in Europe: Politics and Discourse, edited by Ruth Wodak, Majid KhosraviNik, and Brigitte Mral, 267-276. London: Bloomsbury.

Goodwin, Matthew. 2015. "Revolt on the right: UKIP." Hanspeter Kriesi and Takis Spyros Pappas, eds., European Populism in the Shadow of the Great Recession. Colchester, U.K: ECPR Press.

Habermas, Jürgen. 2009. Europe: The Faltering Project. Cambridge: Polity.

2016. "For A Democratic Polarization: How to Pull the Ground from Under Right-wing Populism." Social Europe. URL: https://www.socialeurope.eu/2016/11/democraticpolarisation-pull-ground-right-wing-populism/

Habermas, Jürgen and Jacques Derrida. 2003. "February 15, Or what Binds Europeans Together: A Plea for a Common Foreign Policy, Beginning in the Core of Europe." CONS Constellations 10 (3): 291-297. doi: 10.1111/1467-8675.00333

Hartleb, Florian. 2015. "Here to Stay: Anti-Establishment Parties in Europe.” European View 14 (1): 39-49. doi: 10.1007/s12290-015-0348-4.

Imig, Douglas and Sidney Tarrow. 2001. "Studying contention in an emerging polity." In Contentious Europeans: Protest and Politics in an Emerging Polity, edited by Douglas R. Imig and Sidney G. Tarrow, 3-26. Lanham, Md.: Rowman and Littlefield.

Ioakimoglou, Elias. 2016. "Greece Was the Prologue." Jacobin Magazine. www.jacobinmag.com/2016/08/greece-debt-austerity-syriza-tsipras-grexit-eu/.

Ivarsflaten, Elisabeth. 2008. "What Unites Right-Wing Populists in Western Europe?" Comparative Political Studies 41 (1): 3-23. doi: 10.1177/0010414006294168

Kartizis, Andreas. 2015. "The dilemmas and potentials of the left: learning from SYRIZA." In Socialist Register: The Politics of the Right, edited by Leo Panitch and Gregory Albo. London: The Merlin Press.

Kioupkiolis, Alexandros. 2016. "Podemos: The Ambiguous Promises of Left-Wing Populism in Contemporary Spain." Journal of Political Ideologies 21 (2): 99-120. doi: 10.1080/13569317.2016.1150136

Klandermans, Bert, Marga de Weerd, Jose Manuel Sabucedo, and Mauro Rodriguez. 2001. "Framing contention: Dutch and Spanish farmers confront the EU." In Contentious Europeans: Protest and Politics in an Emerging Polity, edited by Douglas R. Imig and Sidney G. Tarrow, 77-96. Lanham, Md.: Rowman and Littlefield.

Kriesi, Hanspeter, Edgar Grande, Romain Lachat, Martin Dolezal, Simon Bornschier, and Timotheos Frey. 2006. "Globalization and the Transformation of the National Political Space: 
Six European Countries Compared." European Journal of Political Research 45 (6): 921-956. doi: $10.1111 /$ j.1475-6765.2006.00644.x

. 2008. West European Politics in the Age of Globalization. Cambridge, UK; New York: Cambridge University Press.

Kriesi, Hanspeter, Edgar Grande, Martin Dolezal, Marc Helbling, Dominic Höglinger, Swen Hutter, and Bruno Wüest. 2012. Political Conflict in Western Europe. Cambridge; New York: Cambridge University Press.

Kriesi, Hanspeter. 2016. “The Politicization of European Integration.” JCMS: Journal of Common Market Studies 54 (s1): 32-47. doi: 10.1111/jcms.12406

Laclau, Ernesto. 1977. Politics and Ideology in Marxist Theory: Capitalism, Fascism, Populism. London: NLB.

- 2005. On Populist Reason. London; New York: Verso. . 2006. "Why Constructing a People is the Main Task of Radical Politics." Critical Inquiry Critical Inquiry 32 (4): 646-680. doi: 10.1086/508086

- 2011. "On Populist Politics and Parliamentary Paralysis: An Interview with Ernesto Laclau." Interviewed by Rudi Laermans in The Populist Imagination. https://www.onlineopen.org/download.php?id=76

Löwry, Michael and Francis Sitel. 2015. "The far right in France: The Front National in European perspective." In Socialist Register: The Politics of the Right, edited by Leo Panitch and Gregory Albo. London: The Merlin Press.

Mair, Peter. 2007. "Political Opposition and the European Union." GOOP Government and Opposition 42 (1): 1-17. doi: 10.1111/j.1477-7053.2007.00209.x

Maradal, Magnus E. 2013. "Third Way Social Democracy and Right Wing Populism.” In RightWing Populism in Europe: Politics and Discourse, edited by Ruth Wodak, Majid KhosraviNik, and Brigitte Mral, 39-54. London: Bloomsbury.

Mastropaolo, Alfio. 2008. "Politics against democracy: Party Withdrawal and Populist Breakthrough." In Twenty-First Century Populism: The Spectre of Western European Democracy, edited by Daniele Albertazzi and Duncan McDonnell, 30-48. New York: Palgrave Macmillan.

McDonnell, Duncan and Giuliano Bobba. 2015. "Italy: a strong and enduring market for populism." In European Populism in the Shadow of the Great Recession, edited by Hanspeter Kriesi and Takis Spyros Pappas. Colchester, U.K: ECPR Press.

Moffitt, Benjamin. 2015. "How to Perform Crisis: A Model for Understanding the Key Role of Crisis in Contemporary Populism." Government and Opposition 50 (2): 189-217. doi: 10.1017/gov.2014.13 
Montesquieu, Charles de Secondat. 1949. The Spirit of the Laws. New York: Hafner Pub. Co.

Monza, Sabina and Eva Anduiza. 2016. "The Visibility of the EU in the National Public Spheres in Times of Crisis and Austerity." Politics and Policy 44 (3): 499-524. doi: 10.1111/polp.12163

Mouffe, Chantal. 2016. "In defence of left-wing populism." The Conversation, April 29. http://theconversation.com/in-defence-of-left-wing-populism-55869

Negri, Antonio. 2009. Empire and Beyond. Cambridge: Polity.

Oesch, Daniel. 2008. "Explaining Workers' Support for Right-Wing Populist Parties in Western Europe: Evidence from Austria, Belgium, France, Norway, and Switzerland." International Political Science Review 29 (3): 349-373. doi: 10.1177/0192512107088390

Ortiz, Isabel, Sara Burke, Mohamed Berrada, and Hernan Cortes Saenz. 2013. "World Protests 2006-2013." Initiative for Policy Dialogue, http://cadtm.org/img/pdf/world_protests_20062013-final-2.pdf.

Pappas, Takis S. and Paris Aslanidis. 2015. "Greek populism: a political drama in five acts." In European Populism in the Shadow of the Great Recession, edited by Hanspeter Kriesi and Takis Spyros Pappas. Colchester, U.K: ECPR Press.

Pappas, Takis S. and Hanspeter Kriesi. 2015. "Populism and crisis: A fuzzy relationship." In European Populism in the Shadow of the Great Recession, edited by Hanspeter Kriesi and Takis Spyros Pappas. Colchester, U.K: ECPR Press.

Pasquino, Gianfranco. 2008. "Populism and democracy." In Twenty-First Century Populism: The Spectre of Western European Democracy, edited by Daniele Albertazzi and Duncan McDonnell, 15-29. New York: Palgrave Macmillan.

Pelinka, Anton. 2013. "Right wing Populism: Concept and Typology." In Right-Wing Populism in Europe: Politics and Discourse, edited by Ruth Wodak, Majid KhosraviNik, and Brigitte Mral, 3-22. London: Bloomsbury.

Seymour, Richard. 2015. "UKIP and the crisis of Britain." In Socialist Register: The Politics of the Right, edited by Leo Panitch and Gregory Albo. London: The Merlin Press.

Stanley, Ben. 2008. “The Thin Ideology of Populism.” Journal of Political Ideologies 13 (1): 95 110. doi: 10.1080/13569310701822289

Stavrakakis, Yannis and Giorgos Katsambekis. 2014. "Left-Wing Populism in the European Periphery: The Case of SYRIZA.” Journal of Political Ideologies 19 (2): 119-142. doi: 10.1080/13569317.2014.909266

Szczerbiak, Aleks and Paul Taggart. 2004. "The Politics of European Referendum Outcomes and Turnout: Two Models.” West European Politics 27 (4): 557-583. doi: $10.1080 / 0140238042000249920$ 
Tocqueville, Alexis de. 2000. Democracy in America. Translated by Harvey C. Mansfield and Delba Winthrop. Chicago: University of Chicago Press.

Tsakatika, Myrto and Costas Eleftheriou. 2013. "The Radical Left's Turn Towards Civil Society in Greece: One Strategy, Two Paths.” South European Society and Politics 18 (1): 81-99. doi: $10.1080 / 13608746.2012 .757455$

Vampa, Davide. 2015. "Local Representative Democracy and Protest Politics: The Case of the Five-Star Movement." Contemporary Italian Politics Contemporary Italian Politics 7 (3): 232-250. doi: 10.1080/23248823.2015.1087120

Virno, Paolo. 2004. A Grammar of the Multitude: For an Analysis of Contemporary Forms of Life. Los Angeles, CA: Semiotexte.

Wacquant, Loïc and Serge Halimi. 2002. "Jospin pays for the class betrayal of the Socialists." Le Magazine de l'Homme Moderne, April 25 http://www.hommemoderne.org/societe/socio/wacquant/socguar.html

Weber, Max. 1978. Max Weber: Selections in Translation. Edited by Runciman, W.G. Cambridge; New York: Cambridge University Press.

Yla-Anttila, Tuomas and Tuukka Yla-Anttlia. 2015. "Exploiting the discursive opportunity of the euro crisis: the rise of the Finns Party." In European Populism in the Shadow of the Great Recession, edited by Hanspeter Kriesi and Takis Spyros Pappas. Colchester, U.K: ECPR Press.

Zaslove A. 2008. "Here to Stay? Populism as a New Party Type.” European Review 16 (3): 319 336. doi: 10.1017/S1062798708000288

Zizek, Slavoj. 2006a. “Against the Populist Temptation.” Critical Inquiry 32 (3): 551-574. doi: $10.1086 / 505378$

. 2006b. "Schlagend, Aber Nicht Treffend!" Critical Inquiry 33 (1): 185-211. doi: $10.1086 / 509751$ 
Published by the Centre for European Studies at Carleton University, Ottawa, Canada Available online at: journals.carleton.ca/rera/index.php/rera

RERA is an electronic academic peer-reviewed journal that publishes graduate, post-graduate, and young scholarly works. Topics relate to the European Union, its Member States, the former Soviet Union, and Central and Eastern Europe. The journal is a joint project supported by the CanadaEurope Transatlantic Dialogue - a cross-Canada research network supported by the Social Sciences and Humanities Research Council of Canada (SSHRC) — along with the Institute of European, Russian and Eurasian Studies (Carleton University) and its associated research unit, the Centre for European Studies.

RERA aims to provide an accessible forum for research, to promote high standards of research and scholarship, and to foster communication among young scholars.

\section{Contact:}

Carleton University

The Centre for European Studies

1103 Dunton Tower

1125 Colonel By Drive

Ottawa, ON K1S 5B6

Canada

Tel: +01 613 520-2600 ext. 3117; E-mail: rera-journal@ carleton.ca

\section{Creative Commons License}

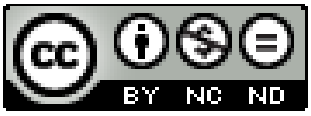

creativecommons.org/licenses/by-nc-nd/3.0

This Working Paper is licensed under a Creative Commons Attribution-Non-CommercialNo Derivs 3.0 Unported License (CC BY-NC-ND 3.0).

Articles appearing in this publication may be freely quoted and reproduced, provided the source is acknowledged. No use of this publication may be made for resale or other commercial purposes.

ISSN: 1718-4835

(C) 2018 The Author(s) 